\title{
Service Redesign General Sharia Insurance - Renewal Account
}

\author{
Amalia Suzianti*, Syabila Anjani, Darisa Syahrini, and Andrien Pramono \\ Universitas Indonesia, Indonesia
}

\section{ARTICLE INFO}

\begin{tabular}{l}
\hline Keywords: \\
Service Redesign \\
TRIZ \\
Service Blueprint \\
Service Quality \\
Insurance
\end{tabular}

\begin{abstract}
On present day, sharia insurance industry is having a significant growth yearly. The annual growth is around 3\%-5\% and potentially could achieve $20 \%$ yearly in growth. This research used the current existing service design element problems in sharia insurance industry as the basis for this research. Steps taken in this research is by using service quality in order to get the needs of the customer. The aims of this research are to design the renewal service of insurance in accordance with the customer needs and provide alternative solutions to the problems by conducting the research in one of sharia insurance companies in Indonesia. Further purpose of this study is to implement the renewal service design recommendation that match the customer needs. The methods used in this research are TRIZ with service quality and service blueprint in seeking the current and improved condition. This research also uses service design method as the basic theory in creating high quality service system in accordance to customer requirements and service redesign method for recreating an improved version of the service. The output of this research is the improved service design recommendation mapped in service blueprint. Furthermore, the research also gives alternative solutions on the existing problem which can be applied to the service.
\end{abstract}

\section{Introduction}

Currently, Sharia Insurance industry in Indonesia has a significant premium growth around 3\% - 5\% per year. According to Sharia Insurance expert, this growth will continue for years and reach 20\% (Asworo, 2015). The number represents the income of all Sharia Insurance Companies in Indonesia, including Asuransi Umum Syariah PT Tugu Pratama Indonesia.

PT. Tugu Pratama Indonesia is one of General Insurance Company which established in 1981 and head office located in Jakarta. The company owned by PT. Pertamina and for the last 10 years has developed the Sharia Insurance Products for several line of business such as Property All Risk (PAR), Motor Vehicle and Personal Liability. These products contribute the gross premium to the overall premium of PT. Tugu Pratama Indonesia. However, for the last couple of years the Sharia Premium Income of PT. Tugu Pratama Indonesia has reduced quite significantly (Indonesia, 2014).

There are two sources of premium income, i.e. new account customer and renewal account customer. New account customer is the customer who just insuring their assets, while renewal account customer is customer who already insuring their assets and renew it periodically.

According to the data of PT. Tugu Pratama Indonesia Sharia Insurance, the comparison of gross premium between new account customer and renewal account customer shows significant difference. In 2012, $98.92 \%$ of total customer is new account customer while the remaining balance of $1.08 \%$ is renewal account customer. In 2013, the percentage of new account customer increased to become $99.02 \%$ of total customer, while the renewal account customer

\footnotetext{
* Corresponding Author E-Mail Address: suzianti@eng.ui.ac.id
} 
reduced to become $0.98 \%$. Until 2014 , the data shows reduction in number of customer who renewing their insurance policies in PT. Tugu Pratama Indonesia Sharia Insurance.

According to Ernst \& Young (2012) there are several reasons why customer renew their insurance policies to certain insurance company, the first is the service, the second is the location of insurance company, and the third is the price (Damtew \& Pagidimarri, 2013). This research will be focusing on the service given by the insurance company. Based on this, the initial survey will be evaluating on the service given by the employee of PT. Tugu Pratama Indonesia Sharia Insurance. The method used is random sampling by interviewing 35 respondents who is customer of PT. Tugu Pratama Indonesia Sharia Insurance.

The result of the survey shows 9\% categorize as "Strongly Not Satisfied", 49\% "Not Satisfied", 11\% "Satisfied Enough", 20\% "Satisfied", and 11\% "Strongly Satisfied".

There are number of reasons for dissatisfaction such as the solution given is not comprehensive, the product information not detail enough, policy contract is not detail, lack of product diversification, less number of listed workshop (for Motor Vehicle Insurance), no virtual account available, less responsive employee, and belated renewal insurance policy notification.

These factors were classified into stages of service given by employee and upon analysing all the stages it shows that the customer dissatisfaction happen almost in every stages. This means that the current customer service design has not managed properly to meet customer's satisfaction.

There are 4 elements affecting the decision whether the customer service re-designing is needed or not, and those elements are environmental setting, processes, job design, and people. In current design of customer service of PT. Tugu Pratama Indonesia Sharia Insurance, these 4 elements are still facing problems (Alfadly, 2012). Therefore, the customer service redesign in strongly needed.

\section{Literature}

\subsection{Service Design}

Definition of service design is the idea to design the high-quality customer service system and to consider and respond to customer's expectation in designing each element of service (Jun, 2004). The purpose of customer service design is to have a continuing process which consistently give high quality service to meet the customer's satisfaction, while keeping the process efficiency. By having the proper customer service design, it is expected that the service given can meet the customer's expectation (Ponsignon, Smart, \& Maull, 2007).

\subsection{Service Redesign}

Service Redesing needs collaboration across departments and customer's support to participate in the process of improving the customer service design. Existing service must be analysed, obsolete assumption must be deleted and customer's perspective must be adopted to improve the current customer service available (Alfadly, 2012).

\subsection{Service Quality}

The tool is used as a facility for customer to reflect the expectation and perception on a problem. Each respondent was asked to score the expectation and performance by using the 5 point likert scale from "strongly disagree" to "strongly agree" so the result will show the gap between positive or negative result (Kulašin \& Fortuny-Santos, 2005).

\subsection{TRIZ}

TRIZ method originally comes from Russia which stands for Theoria Resheneyva Isobretatelskehuh Zadach, which in English called Theory of Innovative Problem Solving (TIPS) (Lin, Chen, \& Chen, 2012). According to Savransky (2000), TRIZ is a systematic problem-solving method based on human orientation knowledge. 
There are several advantages by using TRIZ in problem solving, i.e.:

[1] Simplify the process of finding the qualified ideas in a systematic and effective way.

[2] Produce ideas through some stages in problem solving process.

[3] Solving the problems by formulating some possible alternative solutions.

[4] Support new ideas without trade-off and compromise.

\subsection{Service Blueprint}

Service Blueprint is a tool to see the customer's view, not the company's nor the organization's view. The tool produces various visualization of service process whether it can or cannot be seen by the customer (Milton \& Johnson, 2012; Sampson, 2012). By using Service Blueprint, the employee can understand on what and how a system works to achieve customer's satisfaction (Ellison, Heino, \& Gibbs, 2006).

\section{Research Method}

In solving the problem, TRIZ has 3 steps i.e. problem identification, problem solving and problem evaluation. The description will be scripted in table below.

Table 1.

Steps in Solving Problem using TRIZ

\begin{tabular}{lllll}
\hline Steps & Description & Input & Output & Available Tools \\
\hline $\begin{array}{l}\text { Defining the } \\
\text { problem }\end{array}$ & $\begin{array}{l}\text { Analyse and identify } \\
\text { original problem in Priginal } \\
\text { TRIZ terminology }\end{array}$ & $\begin{array}{l}\text { Identified problem in } \\
\text { TRIZ terminology (ex: } \\
\text { problem modeling) }\end{array}$ & $\begin{array}{l}\text { Questionnaire; functional } \\
\text { analysis; ideal final result; } \\
\text { resource analysis }\end{array}$ \\
\hline $\begin{array}{l}\text { Solving the } \\
\text { problem }\end{array}$ & $\begin{array}{l}\text { Giving the perfect } \\
\text { tools in solving the problem } \\
\text { identified problem }\end{array}$ & $\begin{array}{l}\text { Solution provided (ex: } \\
\text { eliminating } \\
\text { contradiction) }\end{array}$ & $\begin{array}{l}\text { separation } \\
\text { ARIZ }\end{array}$ \\
\hline $\begin{array}{l}\text { Evaluating } \\
\text { the solution }\end{array}$ & $\begin{array}{l}\text { Choosing the most } \\
\text { ideal result perfect for } \\
\text { the situation }\end{array}$ & Alternatives & $\begin{array}{l}\text { Choosen solution for the } \\
\text { original problem }\end{array}$ & Most ideal final result \\
\end{tabular}

Source: (Jun, 2004)

\subsection{Data Type and Collection Method}

The type of data used in this research is primary and secondary data. Primary Data is the data taken directly while doing the research, and Secondary Data is data that already processed and given by the institution (in this case PT. Tugu Pratama Indonesia). The Primary Data used in this research is the data obtained by doing interview dan questionnaire method and using Likert scale in relates to the level of interest and work performance of the employee in giving service to Sharia Insurance customer of PT. Tugu Pratama Indonesia. The Secondary Data used is the service concept and gross premium income of PT. Tugu Pratama Indonesia Sharia Insurance.

\subsection{Research Population and Sample}

In this research the target of customer population is the customer who already get the Sharia Insurance services for the last 10 months (January 2015 - October 2015). Data collection is using the sampling method and will be processed by TRIZ method. Based on theory, minimum 96 respondents needed to participate in research sampling of improving the service quality by using TRIZ method (LariSemnani, Far, Shalipoor, \& Mohseni, 2015). In this research, there are 101 respondents.

\subsection{Questionnaire Data}

Questionnaire data dominated by male respondents around $70 \%$, while female respondents is $30 \%$. Age range is 20-29 years of age for 40\%, 30-39 years of age for 25\%, 40-49 years of age 
for $23 \%$, and above 50 years of age is $13 \%$. In terms of occupation, $80 \%$ of respondents is private employee, $13 \%$ is businessmen, $6 \%$ is state employee and $1 \%$ is student. The sharia insurance product classified as motor vehicle for $48 \%$, property all risk for $44 \%$ and personal liability insurance for $9 \%$.

Based on dimensions used to see the sample questionnaire from literature (Ahmad \& Sungip, 2008), the questions were classified. By using the service quality method, the result of the questionnaire shows the level of expectation of customer service excellence. The average of level of expectation, performance and gap of service dimensions were calculated and the result is shown in table below.

Table 2.

Dimension and Data Collected from Questionnaire

\begin{tabular}{|c|c|c|c|c|c|}
\hline Dimensions & Var & Questions & Imp & Perf & Gap \\
\hline \multirow{3}{*}{ Tangibility } & T1 & Office appearance & 4,117647059 & 3,735294118 & $-0,382352941$ \\
\hline & $\mathrm{T} 2$ & Worker appearance & 4,176470588 & 3,882352941 & $-0,294117647$ \\
\hline & $\mathrm{T} 3$ & $\begin{array}{l}\text { The office matches the } \\
\text { service }\end{array}$ & 4,058823529 & 3,852941176 & $-0,205882353$ \\
\hline \multirow{7}{*}{ Reliability } & R1 & $\begin{array}{l}\text { Keeping promises on- } \\
\text { time }\end{array}$ & 4,073529412 & 3,911764706 & $-0,161764706$ \\
\hline & $\mathrm{R} 2$ & Sympathic workers & 4,102941176 & 3,882352941 & $-0,220588235$ \\
\hline & R3 & $\begin{array}{l}\text { Service match the } \\
\text { expectation }\end{array}$ & 4,132352941 & 3,970588235 & $-0,161764706$ \\
\hline & $\mathrm{R} 4$ & Reliable worker & 4,264705882 & 3,808823529 & $-0,455882353$ \\
\hline & R5 & On-time services & 4,191176471 & 3,705882353 & $-0,485294118$ \\
\hline & R6 & $\begin{array}{l}\text { Having accurate record } \\
\text { data }\end{array}$ & 4,147058824 & 3,823529412 & $-0,323529412$ \\
\hline & R7 & Services are guaranteed & 4,191176471 & 3,823529412 & $-0,367647059$ \\
\hline \multirow{3}{*}{ Responsiveness } & RS1 & $\begin{array}{l}\text { Always informing when } \\
\text { are the services } \\
\text { performed }\end{array}$ & 4,044117647 & 3,705882353 & $-0,338235294$ \\
\hline & $\mathrm{RS} 2$ & Giving time to response & 4,161764706 & 3,823529412 & $-0,338235294$ \\
\hline & RS3 & $\begin{array}{l}\text { Eliminate customer } \\
\text { waiting time }\end{array}$ & 4,235294118 & 3,867647059 & $-0,367647059$ \\
\hline \multirow{5}{*}{ Assurance } & A1 & Trustworthy and honest & 4,52238806 & 4,059701493 & $-0,455882353$ \\
\hline & $\mathrm{A} 2$ & Assuring & 4,28358209 & 4,059701493 & $-0,220588235$ \\
\hline & A3 & Polite & 4,279411765 & 3,970588235 & $-0,308823529$ \\
\hline & A4 & $\begin{array}{l}\text { Have knowledge and } \\
\text { competent }\end{array}$ & 4,176470588 & 3,897058824 & $-0,279411765$ \\
\hline & A5 & Have enough experience & 4,161764706 & 3,808823529 & $-0,352941176$ \\
\hline \multirow{6}{*}{ Empathy } & E1 & Caring & 3,985294118 & 3,897058824 & $-0,088235294$ \\
\hline & E2 & Understanding & 4,058823529 & 3,941176471 & $-0,117647059$ \\
\hline & E3 & $\begin{array}{l}\text { Informing any changes } \\
\text { applied }\end{array}$ & 3,985294118 & 3,794117647 & $-0,191176471$ \\
\hline & E4 & Communicate & 4,161764706 & 3,823529412 & $-0,338235294$ \\
\hline & E5 & $\begin{array}{l}\text { Giving best business } \\
\text { time }\end{array}$ & 3,882352941 & 3,573529412 & $-0,308823529$ \\
\hline & E6 & Available & 4,102941176 & 3,720588235 & $-0,382352941$ \\
\hline
\end{tabular}

In composing the problem identification requires data from the customer service gap. This service gap reflects the dissatisfaction felt by the customer towards the service given. The dimension used in problem identification determined after discussed it with the PT. Tugu Pratama Indonesia authority. The outcome of the discussion regarding the problem formulation reflects in cause and effect diagram by using the function-link-function diagram. 


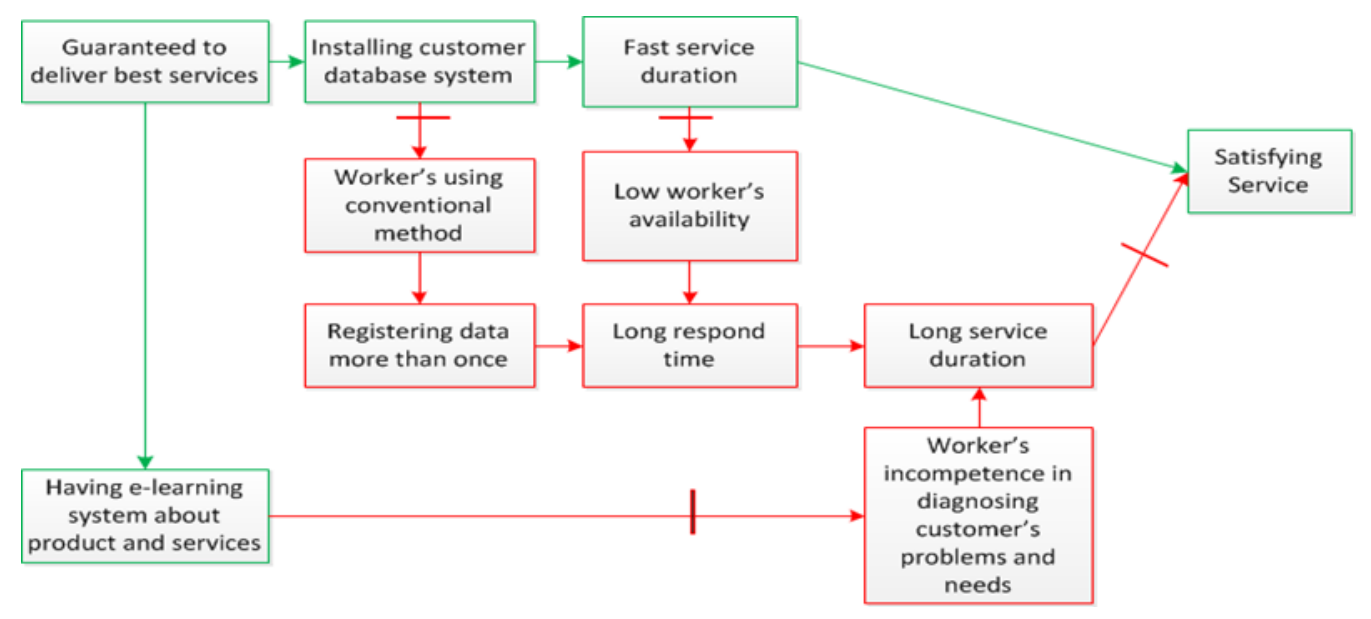

Figure 1. Function-link-function Diagram

The above diagram describes the overall identified problems. Begin with the service goal i.e. to satisfy the customer. The goal was transformed into useful function at the beginning and the end of the diagram. In managing the service toward the intended goal, there are several efforts have to be done. These efforts are defined as useful function.

The barriers that occur in achieving the goal defined as harmful function in the diagram. These barriers can slow down the company's process to achieve the goal, therefore it is stated as problem statement to simplify the problem identification.

Based on the above function- link-function diagram, the problem identification was defined in below statements:

Table 3.

Problem Statement

\begin{tabular}{ll}
\hline No & Problem Statement \\
\hline 1 & $\begin{array}{l}\text { Find alternative to deliver satisfying services by giving service in timely manner by eliminating the low } \\
\text { productivity employee. }\end{array}$ \\
\hline 2 & Find ways to deliver satisfying services by not using fast services duration. \\
\hline 3 & $\begin{array}{l}\text { Find alternative to deliver satisfying services by installing customer database system by eliminating the } \\
\text { use of conventional methods. }\end{array}$ \\
\hline 4 & $\begin{array}{l}\text { Find alternative to deliver satisfying services by having e-learning system for educating workers about } \\
\text { the services and the product by eliminating the worker's incompetence of diagnosing the problem/needs } \\
\text { of customer. }\end{array}$ \\
\hline 5 & $\begin{array}{l}\text { Find ways to solve the trade-off of having e-learning system giving satisfying services by eliminating } \\
\text { worker's incompetence f diagnosing the problem/needs of customer. }\end{array}$ \\
\hline 6 & $\begin{array}{l}\text { Find ways to eliminate registering data more than once into the system which causing the long respond } \\
\text { time while worker's are using conventional methods. }\end{array}$ \\
\hline 7 & Find ways to increase effectivity in delivering satisfying services. \\
\hline 8 & Find other benefits in having e-learning system. \\
\hline 9 & Find alternative to deliver satisfying services without using e-learning system. \\
\hline 10 & Find ways to make benefits of having long time services \\
\hline 11 & $\begin{array}{l}\text { Find ways to solve the trade-off of fast services in delivering satisfying service by eliminating } \\
\text { worker's availability which causing long respond time. }\end{array}$ \\
\hline 12 & Find ways to eliminate long respond time which cause long service duration in low worker availability. \\
\hline
\end{tabular}

The above Problem statement then being summarize and classified into 4 characteristics i.e., service duration, employee competency, employee availability and service effectiveness.

The 4 service characteristic were translated into TRIZ method in contradictory analysis by having improving parameter and worsening parameter from each service characteristic. These parameters will be resulting contradictory while improvement in service quality being done. 
By analyzing using the contradictory matrix, some inventive principles of alternative solution which can be applied into improved service blueprint were found.

The service starts by customer receiving notification for renewal account. To deliver the notification, contact data of the customer must be searched then renewal notification letter must be constructed. If the customer wants to renew his/her account, then the customer must wait for the front liner. After the customer receive his/her renewal offer letter, the system will send the description of its product through e-learning. Should the customer choose to accept the offer, the customer will give confirmation for extension and send the necessary data. Then, the customer will receive the insurance policy and invoice. To proceed, the customer must make a payment for the next period and give feedbacks to the service.

The problems identified will be described in service blueprint actual as failure point.

There are several failure points in service blueprint actual i.e.:

- Longer service duration due to the employee are not using customer database system.

- Customer consultancy with employee depends on the availability of such employee.

- Employee competency in analyzing and giving advice regarding the product which suitable with the customer's need.

Based on the above processed data, there are several inventive principles obtained in doing the contradictory analysis. To choose the proper inventive principles, a discussion with the company's authority were taken to find a solution that can be applied in the company's customer service.

Table 4.

Contradiction Analysis and Determining Solution

\begin{tabular}{|c|c|c|c|c|}
\hline Dimensions & $\begin{array}{l}\text { Improving } \\
\text { Parameter }\end{array}$ & $\begin{array}{l}\text { Worsening } \\
\text { Parameter }\end{array}$ & Inventive Principles & $\mathbf{Y} / \mathbf{N}$ \\
\hline \multirow{4}{*}{ Services Duration } & \multirow{4}{*}{$\begin{array}{l}(09) \\
\text { Responsiveness- } \\
\text { Speed }\end{array}$} & \multirow{4}{*}{$\begin{array}{l}(27) \\
\text { Reliability }\end{array}$} & (11) Beforehand Cushioning & $\mathrm{Y}$ \\
\hline & & & (35) Parameter Changes & $\mathrm{Y}$ \\
\hline & & & (27) Cheap Disposable & $\mathrm{N}$ \\
\hline & & & (28) Mechanic Substitution & $\mathrm{Y}$ \\
\hline \multirow{3}{*}{ Worker's Competency } & \multirow{3}{*}{$\begin{array}{l}\text { (14) Professional } \\
\text { Competence }\end{array}$} & \multirow{3}{*}{$\begin{array}{l}\text { (19) Labor } \\
\text { intensive }\end{array}$} & (19) Periodic Action & $\mathrm{Y}$ \\
\hline & & & (35) Parameter Changes & $\bar{Y}$ \\
\hline & & & (10) Preliminary Action & $\mathrm{Y}$ \\
\hline \multirow{3}{*}{ Worker's Availability } & \multirow{3}{*}{ (35) Empathy } & \multirow{3}{*}{ (09) Speed } & (35) Parameter Changes & $\bar{Y}$ \\
\hline & & & (10) Preliminary Action & $\mathrm{Y}$ \\
\hline & & & (14) Spheroidality & $\mathrm{N}$ \\
\hline \multirow{8}{*}{ Services Effectivity } & \multirow{8}{*}{ (39) Performa } & \multirow{4}{*}{ (30) Factors } & $\begin{array}{l}\text { (22) "Blessing in Disguise" or } \\
\text { "Turns Lemon into } \\
\text { Lemonade" }\end{array}$ & $\mathrm{Y}$ \\
\hline & & & (35) Parameter Changes & $\mathrm{Y}$ \\
\hline & & & (13) The Other Way Around & $\mathrm{N}$ \\
\hline & & & (24) Intermediary & $\mathrm{N}$ \\
\hline & & \multirow{4}{*}{$\begin{array}{l}\text { (34) Service } \\
\text { Capabilities }\end{array}$} & (01) Segmentation & $\mathrm{Y}$ \\
\hline & & & (32) Color Changes & $\mathrm{N}$ \\
\hline & & & (10) Preliminary Action & $\bar{Y}$ \\
\hline & & & (25) Self-service & $\bar{Y}$ \\
\hline
\end{tabular}




\section{Conclusion}

Previous condition in current service blueprint has three failure points i.e. service duration, employee availability, and employee competency. Each failure point has its own characteristic. For more details, please see Appendix 2. First Failure point (FP) is regarding the service duration which included in the initial process of sending renewal notification to customer.

The second failure point is according to worker's availability in giving time for customer consultancy. And the third failure point is about the worker's competency in diagnosing the needs of the customer.

The inventive principles mapping into the improved service blueprint done by in-depth interview method with the corporate representatives to match the alternatives solution composed in the research according to the original problems. These are the list of improved action mapped in the improved service blueprint.

[1] Action plan to reduce and make benefits of services duration by

- Separating underwriting division based on each product which are PAR, Personal liability, and motor vehicle

- Implementing the renewal notification system

- Implementing the automatic renewal hold coverage system in case of emergency

[2] Action plan to increase the worker's competency by

- Having training on low demand season to prepare workers for high demand season

[3] Action plan to increase the worker's availability by

- Implementing call centre

- Updating the website information by adding guidelines and partners (ex: hospitals, etc)

- Making phonebook of customer contacts

- Using database system

[4] Action plan to increase service effectivity by

- Implementing complaint management

- Implementing Tugu Web Access

\section{Acknowledgements}

This work is supported by Hibah PIT 9, funded by Directorate of Research and Community Service (DRPM) Universitas Indonesia, No. NKB-0041/UN2.R3.1/HKP.05.00/2019.

\section{References}

Ahmad, A., \& Sungip, Z. (2008). An Assessment on Service Quality in Malaysia Insurance Industry. Communications of the IBIMA. Kuala Lumpur, Malaysia, pp. 13-26.

Alfadly, D. A. (2012). Improving the Quality of Services Marketing in Kuwaiti Organizations. International Journal of Humanities and Social Science.

Asworo, H. T. (February 2015). Bisnis Syariah. Available: http://syariah.bisnis.com/read/20150202/232/397771/kinerja-asuransi-syariah-premiterendah-dalam-4-tahun-terakhir

Avicenna. (2015). Service Redesign dengan Metode Factor Analysis, TRIZ, dan Service Blueprint (Studi Kasus: Kantor Penjualan Garuda Indonesia Senayan City). Universitas Indonesia, Depok. 
Berry, L. L., \& Lampo, S. K. (2000). Teaching an Old Service New Tricks: The Promise of Service Redesign. Journal of Service Research.

Bitner, M. J., Ostrom, A. L., \& Morgan, F. N. (2007). Service Blueprinting: A Practical Technique for Service Innovation. Working Paper in Center for Services Leadership in Arizona State University.

Damtew, K., \& Pagidimarri, D. (2013). The role of "trust" in building customer loyalty in insurance sector- A study. IOSR Journal of Business and Management (IOSR-JBM).

Gazem, N., \& Rahman, A. A. (2014). Interpretation of TRIZ Principles in a Service Related Context. Asian Social Science, 108-130.

Indonesia, T. P. (2014). Annual Report. Jakarta.

Johnson, N., \& Smogner, P. (2013). How to enhance Shareholder Value through a Customer support in the Insurance industry: A business driven approach towards Business Intelligence. Stockholm: Master of Science Thesis in KTH Industrial Engineering and Management.

Jun, Z. (2004). Systematic Innovation in Service Design Through TRIZ. Thesis in National University of Singapore.

Kulašin, D., \& Fortuny-Santos, J. (2005). Review of The Servqual Concept. 4th Research/Expert Conference with International Participation "QUALITY 2005”. Fojnica, Bosnia and Herzegovina.

LariSemnani, B., Far, R. M., Shalipoor, E., \& Mohseni, M. (2015). Using Creative Problem Solving (TRIZ) in Improving the Quality of Hospital Service. Global Journal of Health Science.

Lin, S.-P., Chen, C.-P., \& Chen, J.-S. (2012). Using TRIZ-based Method to Improve Health Service Quality: A Case Study on Hospital. 2nd International Conference on Economics, Trade and Development. Singapore.

Lina, C.-S., \& Sub, C.-T. (2007). An Innovative Way to Create New Services: Applying the TRIZ Methodology. Journal of the Chinese Institute of Industrial Engineers.

Ponsignon, F., Smart, D. P., \& Maull, P. R. (2007). Service Delivery Systems: The Transformational Context. Discussion Paper in Management in University of Exeter.

Ratnasari, N. G. (2009). Perbedaan Faktor-faktor yang Mempengaruhi Adopsi Penggunaan Unit Link Syariah dan Konvensional. Universitas Indonesia, Jakarta.

Teixeira, J., Patrício, L., Nunes, N. J., Nóbrega, L., \& P., R. (2012). Customer Experience Modeling: from Customer Experience to Service Design. Journal of Service Management.

Wreiner, T., Mårtensson, I., Arnell, O., Gonzalez, N., Holmlid, S., \& Segelström, F. (2009). Exploring Service Blueprints for Multiple Actors: A Case Study of Car Parking Services. First Nordic Conference on Service Design and Service Innovations. Oslo, Norway.

Zlotin, B., \& Zusman, A. (2001). Directed Evolution Philosophy, Theory, and Practice. The First Symposium on TRIZ Methodology and Application. Southfield, United States, pp. 92. 